УДК 65.0. 371

Степашко Володимир Олексійович

доктор педагогічних наук, професор кафедри менеджменту, доцент

ДВНЗ «Переяслав-Хмельницький державний педагогічний університет імені Григорія Сковороди»,

Переяслав-Хмельницький, Україна

ORCID 0000-0002-1367-6056

quality16@i.ua

\title{
ПРОГРАМНІ ЗАСОБИ ДЛЯ ВІДБОРУ І ФОРМУВАННЯ ВИКЛАДАЦЬКОГО ПЕРСОНАЛУ ЗАКЛАДУ ВИЩОЇ ОСВІТИ
}

\begin{abstract}
Анотація. У статті викладено проблему автоматизованого відбору кандидатів на вакантні посади i формування якісного складу науково-педагогічних працівників засобами спеціальної комп'ютерної програми. Актуальність проблеми полягає в необхідності відбору і формування конкурентоспроможного персоналу, здатного забезпечити якісні освітні послуги споживачам на основі новітніх інформаційних технологій. Розроблено аналітичну технологію підтримки ухвали рішення в управлінні процесом відбору і формування викладацького персоналу, зокрема, модель системи відбору і формування якісного складу викладацького персоналу, складники професіограми викладача, факторно-критеріальну субмодель для оцінювання компонентів результативності професійної діяльності науковопедагогічних працівників, спеціальну комп'ютерну програму для з'ясування професійної спроможності претендентів. Оцінювання професійної придатності й моніторинг якісних показників професійної діяльності претендентів у процесі відбору, формування та розвитку викладацького персоналу здійснено на основі методів професіографічного аналізу діяльності, факторно-критеріального моделювання, комп'ютерного програмування, експертного оцінювання. Виокремлено чинники, зокрема, «готовність претендентів до професійної діяльності», «якості особистості», «професійна компетентність», «умови формування професійної компетентності» та відповідно до них компоненти результативності професійної діяльності. На основі розробленої кваліметричної факторнокритеріальної субмоделі визначено рівень сформованості компонентів професійної діяльності науково-педагогічних працівників відповідно до головного критерію «результативність професійної діяльності», факторну вагу та ранговий ряд складників педагогічного професіоналізму. Високий ранговий ряд мають показники «ставлення до справи, соціальна активність, естетична та фізична культура».
\end{abstract}

Ключові слова: заклад вищої освіти; технологія; професійний відбір; науково-педагогічні працівники; організаційна модель; комп'ютерна програма; критерії оцінювання якостей.

\section{1.ВСТУП}

Постановка проблеми. Важливим завданням на сучасному етапі розбудови вищої школи є формування нової генерації освітян з високим рівнем професіоналізму, корпоративної культури. Кадрове забезпечення навчально-виховного процесу вищої школи - організаційна умова успішної реалізації Державної національної програми «Освіта: Україна XXI століття». Зміст діяльності закладів вищої освіти (3ВО) узалежнений від якості процесів відбору і формування керівниками професорськовикладацького складу. Результативність навчальної, методичної, організаційної, виховної роботи ЗВО забезпечується процесом науково обгрунтованого відбору i формування викладацького персоналу, створенням організаційних, педагогічних, психологічних умов, що уможливлюють успішну реалізацію мети діяльності ЗВО.

Об’сктивні документи, дані (першоджерела). На посади науково-педагогічних працівників (НПП) колегіальний орган 3ВО обирає осіб, які мають повну вищу освіту, наукові ступені, вчені звання, стаж наукової, науково-педагогічної роботи та (або) 
досвід практичної діяльності, а також випускники магістратури, аспірантури, докторантури, які відповідають затвердженим кваліфікаційним вимогам на ці посади [1].

У розділі $\mathrm{X}$ «Учасники освітнього процесу» Закону України «Про вищу освіту» зазначено, що «під час заміщення вакантних посад викладачів укладенню контракту передує конкурсний відбір; порядок його проведення затверджується вченою радою $3 \mathrm{BO} »[2, \mathrm{c} .16]$.

Конкурс - спеціальна форма відбору НПП на вакантні посади, які за своїми якостями найбільше відповідають професійно-кваліфікаційним вимогам сучасної вищої школи до відповідних посад; конкурсний відбір полягає у перевірці професійного рівня, теоретичних знань, практичних навичок осіб, які претендують на заміщення вакантної посади НПП [10]. Водночас Статутом ЗВО можуть встановлюватися додаткові вимоги до претендентів на посади НПП [2, с. 16]. Серед посад, визначених Законом України «Про вищу освіту», передбачено посади старшого викладача, викладача, асистента, викладача-стажиста [2]. Рекомендовано попереднє обговорення кандидатур претендентів на заміщення посад НПП трудовим колективом кафедри в їх присутності; висновки кафедри про якості претендентів варто затверджувати таємним голосуванням і передавати на розгляд конкурсної комісії разом з окремими висновками учасників засідання, які викладені в письмовій формі [3].

Аналіз останніх досліджень і публікацій. Питання професійного відбору підготовлених педагогів на посади викладачів вищої школи є актуальним у зв’язку з необхідністю формування конкурентоздатного персоналу (M. А. Бермант, А. А. Стогній, Т. Х'юсен), підвищення ефективності управління процесами підготовки кадрів. Питання розвитку комп'ютерної освіти у вищій технічній школі України розглянуто в праці В. Бикова, Г. Гуржія, Г. Козлакової [4]. Застосування основних положень теорії нечітких множин для опису показників оцінки компетентності експерта з використанням лінгвістичних змінних замість числових або в доповнення до них обгрунтовано в праці Г. Терещук та І. Цідило [5]. Описано методику проектування інформаційних систем підтримки ухвали рішення (СППР), яка грунтується на сучасних принципах системного аналізу [6]. Багатокритеріальні задачі нечіткого математичного програмування розглянуто в праці $Є$. Зайченко та Ю. Зайченко [7]. Теоретичні й методичні основи застосування інформаційних технологій у вищій технологічній освіті висвітлено в праці Г. Козлакової [8]. Особливості автоматизованих систем управління ЗВО зазначені в праці О. Співаковського [9]. Питання вдосконалення відбору персоналу засобами сучасних інформаційних технологій розглянуто в праці Х. Опаріної та К. Ковалевської [10]. Г.Сльникова розробила нормативні факторнокритеріальні моделі суб'єктів освітньої діяльності [11]. Актуальним у зв'язку з цим постає питання психолого-педагогічної готовності суб'єктів управління до процесу відбору викладацького персоналу засобами новітніх IКТ у ЗВО [12], [13] (мова йде про наявність в арсеналі керівників локальних нормативних документів, розробленої аналітичної технології підтримки ухвали рішення, ефективної методики діагностичного відбору, спеціального програмного, методичного забезпечення). Проте особливо актуальною $\epsilon$ проблема розроблення й практичного застосування комп'ютерної програми для визначення професійної придатності претендентів на посади викладачів та моніторингу рівня професійного розвитку НПП.

Мета (постановка завдання). Потребує розроблення й практичного застосування спеціальних програмних засобів підтримки ухвали управлінського рішення під час прийому викладачів на конкурсній основі. Мета полягає в розробленні спеціальної автоматизованої програми для відбору кандидатів на посади викладачів і формування якісного складу науково-педагогічних працівників ЗВО. 
Невирішені аспекти проблеми. Аналіз праць вчених дає підстави констатувати, що нині в Україні відсутня чітко розроблена система відбору викладацьких кадрів для ЗВО на автоматизованій основі. Прийом працівника на роботу тут здебільшого здійснюється відповідно до потреб у кадрах і можливостей соціального довкілля. Прогалини в теорії моделювання управлінської діяльності, методичного, програмного забезпечення процесів відбору й формування викладацького персоналу залишають простір для пошуку шляхів підвищення ефективності відбору і формування якісного кадрового складу ЗВО.

\section{2. МЕТОДИ ДОСЛІДЖЕННЯ}

Відповідно до мети обрано такі методи: професіографічний аналіз діяльності, факторно-критеріальне моделювання, комп'ютерне програмування, експертне оцінювання якісних показників результативності професійної діяльності.

\section{3. РЕЗУЛЬТАТИ ДОСЛІДЖЕННЯ}

Конкурсний відбір претендентів на посади НПП керівник ЗВО організовує в чотири етапи.

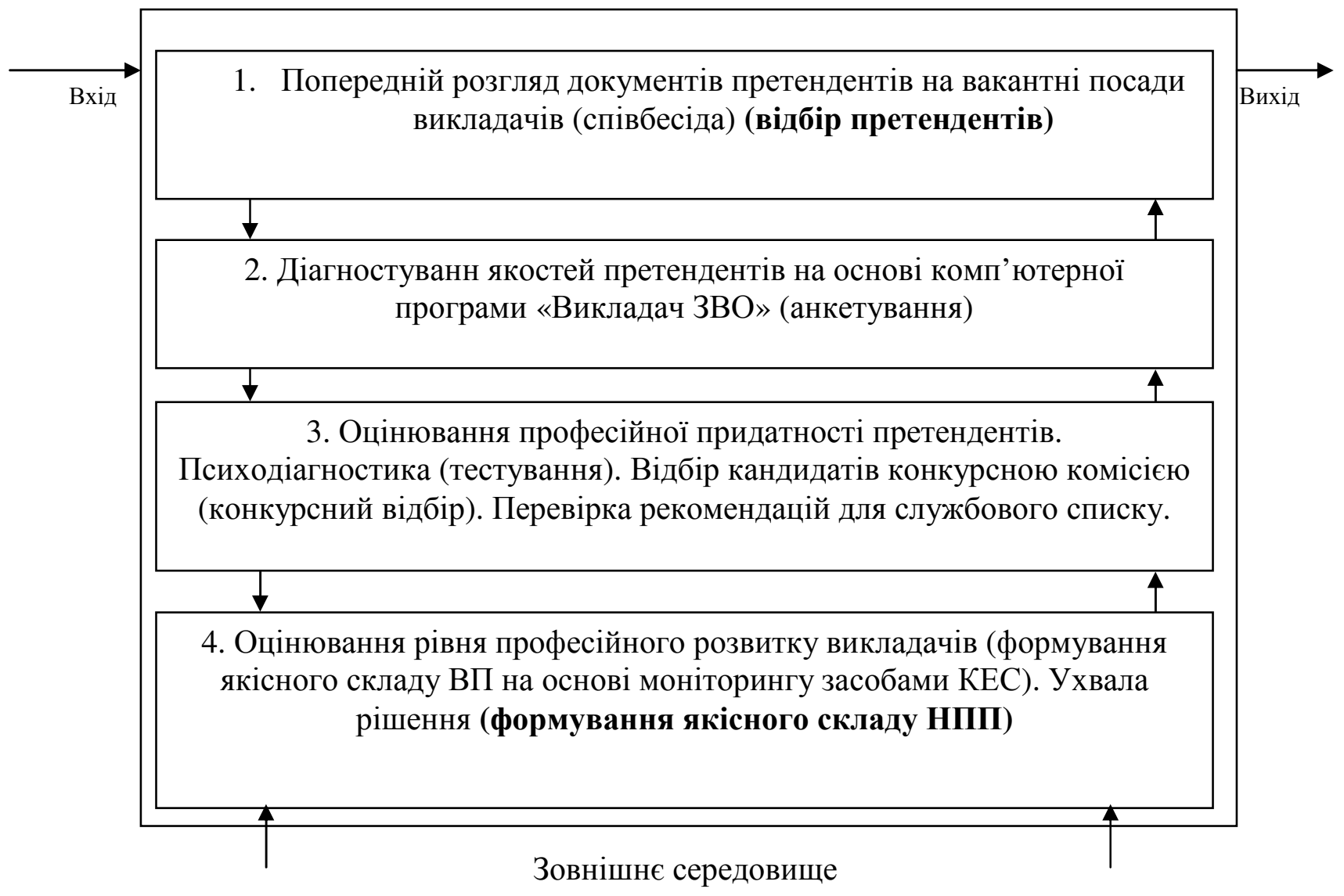

Рис. 1. Організаційна модель системи відбору і формування якісного складу викладацького персоналу

Перший етап - попередній розгляд документів (заяв кандидатів, резюме), який проводиться у формі співбесіди. На другому етапi адміністрація ЗВО організовує діагностування професійних, ділових, особистісних, морально-етичних якостей претендентів засобами комп'ютерних експертних систем на основі методу анкетування. 
На третьому етапі керівник ЗВО організовує оцінювання професійної придатності претендентів через психологічну діагностику на основі методу тестування щодо відповідності встановленим кваліфікаційним вимогам до відповідної посади і відбір кандидатів конкурсною комісією (вона враховує результати співбесіди та комп'ютерного діагностування). На четвертому етапі адміністрація 3ВО, студенти оцінюють професійний рівень викладачів, які протягом п'яти років обіймають посади НПП відповідно до функціонально-посадових обов'язків на основі методу рейтингування (рис.1). Процедуру рейтингування НПП адміністрація ЗВО організовує на підставі даних характеристики рівня наукової і професійної активності викладача (за п'ять років), звітів про перебування на посаді, зокрема, навчальну, наукову, методичну, організаційну роботу; даних щодо атестації, підвищення кваліфікації, показників рейтингового оцінювання професійної діяльності НПП (за один рік) відповідно до переліку якісних показників за 100-бальною шкалою (рис.1).

Відповідно до моделі, окрім нормативних вимог до претендентів на посади НПП, організовано діагностичне експертне оцінювання якісних показників персонограми i психограми, зокрема, анкетування (анкета № 1) на основі комп’ютерної програми «Викладач 3ВО» для 3'ясування відповідності претендента вимогам професії. Запитання анкети адаптовано до змісту якісних показників персонограми і психограми. До анкети включено також запитання, сутність яких не визначено в Положенні [1], проте слугували додатковою інформацією, яка висвітлювала здобутки кандидата (кількість публікацій, мотивація до фахового зростання та ін.).

Ідентифіковано такі складники професіограми викладача: це персонограма, психограма, дескриптограма, акмеограма (табл. 1).

Таблиия 1

\section{Складники професіограми викладача 3ВО}

\begin{tabular}{|c|c|}
\hline Персонограма & Психограма \\
\hline $\begin{array}{l}\checkmark \text { Кваліфікація (базова освіта) } \\
\checkmark \text { Якості (особистісні, професійні, ділові, } \\
\text { морально-етичні) } \\
\checkmark \text { Професіоналізм (компетентність, управлінська } \\
\text { майстерність) } \\
\checkmark \\
\text { Спеціальні (управлінські компетенції) (знання, } \\
\text { уміння, оволодіння навичками, прийомами } \\
\text { професійної діяльності: аналіз даних, організації } \\
\text { процесу) } \\
\checkmark \text { Рівень управлінської підготовки } \\
\checkmark \text { Управлінські ролі (лідера, стратега, } \\
\text { координатора діяльності персоналу; } \\
\quad \text { організатора розподілу ресурсів, ведення } \\
\text { переговорів; інформатора, консультанта, } \\
\text { фасилітатора). }\end{array}$ & $\begin{array}{l}\checkmark \text { Внутрішні мотиви (потреби, інтереси, прагнення) } \\
\checkmark \text { Здатності } \\
\checkmark \text { Психофізіологічні властивості (темперамент, } \\
\text { характер, вольові якості) } \\
\checkmark \text { Я-концепція (установки, цінності) } \\
\checkmark \text { Творчий потенціал } \\
\checkmark \text { Стресостійкість } \\
\checkmark \text { Саморефлексія } \\
\checkmark \text { Самоактуалізація } \\
\checkmark \text { Готовність здійснювати керівництво персоналом } \\
\quad \text { організації }\end{array}$ \\
\hline Дескриптограма & Акмеограма \\
\hline $\begin{array}{ll}\checkmark & \text { Автономність } \\
\checkmark & \text { Відповідальність за результати діяльності ВНЗ } \\
\checkmark & \text { Інтеграція в освітній і науковий простір } \\
& \text { (комунікація) } \\
\checkmark & \text { Прозорість результатів діяльності }\end{array}$ & $\begin{array}{ll}\checkmark & \text { Посада } \\
\checkmark & \text { Науковий ступінь } \\
\checkmark & \text { Вчене звання } \\
\checkmark & \text { Публікаційна активність } \\
\checkmark & \text { Державні нагороди } \\
\checkmark & \text { Почесні звання } \\
\checkmark & \text { Підвищення кваліфікації, стажування за } \\
& \text { кордоном } \\
\checkmark & \text { Інноваційна активність }\end{array}$ \\
\hline
\end{tabular}

На етапі формування якісного складу НПП організовано моніторинг якісних показників дескриптограми й акмеограми для визначення рівня сформованості 
професіоналізму науково-педагогічних працівників засобами спеціалізованої комп’ютерної системи. Запитання анкети № 2 адаптовано до змісту якісних показників дескриптограми й акмеограми.

У типовій професіограмі, окрім групи якостей (особистісних, професійних, ділових, морально-етичних) конкретизовано нормативні якісні показники професійної придатності претендента на вакантну посаду викладача.

Визначено такі рівні професійної діяльності НПП на основі діагностичного оцінювання якісних показників професійної компетентності, характеристики яких відповідають посадовим функціям: формально-виконавчий рівень (знання основних вимог до викладацької діяльності, виконання професійних обов'язків); репродуктивний рівень (діяльність за алгоритмом, задоволення освітніх потреб студентів, методичне, організаційне, інформаційне забезпечення навчального процесу); конструктивний рівень (розроблення науково-методичного забезпечення НДДС, планування організаційних заходів, наукове консультування студентів, використання нововведень); творчий рівень (розроблення й упровадження авторських курсів, наукові розробки, наявність винагород) (параметри рівня - від 0 до 1,0 ) (табл. 2).

Таблиия 2

Рівні професійної діяльності науково-педагогічних працівників

\begin{tabular}{|l|l|}
\hline \multicolumn{1}{|c|}{$\begin{array}{c}\text { Рівні професійної } \\
\text { діяльності НПП }\end{array}$} & \multicolumn{1}{c|}{ Характеристика рівнів } \\
\hline $\begin{array}{l}\text { Формально-виконавчий } \\
\text { рівень (від 0 до 0,50) }\end{array}$ & $\begin{array}{l}\text { Знання основних вимог до викладацької } \\
\text { діяльності; виконання професійних обов’ язків }\end{array}$ \\
\hline $\begin{array}{l}\text { Репродуктивний рівень (від } \\
0,51 \text { до 0,65) }\end{array}$ & $\begin{array}{l}\text { Діяльність за алгоритмом; задоволення } \\
\text { освітніх потреб студентів; ведення документації з питань організації } \\
\text { навчального процесу, науково-дослідницької діяльності студентів }\end{array}$ \\
\hline $\begin{array}{l}\text { Конструктивний рівень } \\
\text { (від 0,66 до 0,75) }\end{array}$ & $\begin{array}{l}\text { Розроблення науково-методичного забезпечення НДДС; планування } \\
\text { НДДС; наукове консультування студентів; використання нововведень }\end{array}$ \\
\hline $\begin{array}{l}\text { Творчий рівень (від 0,76 } \\
\text { до 1,0) }\end{array}$ & $\begin{array}{l}\text { Розроблення і використання в навчально-науковому процесі } \\
\text { авторських курсів; наукові розробки; наявність винагород }\end{array}$ \\
\hline
\end{tabular}

Обчислення балів здійснювалося на основі методики, розробленої Г. Єльниковою [11, с. 314]. Для оцінювання компонентів результативності професійної діяльності НПП на етапі їх формування і розвитку розроблено адаптовану до умов функціонування 3ВО факторно-критеріальну субмодель (ФКС) на основі методики, розробленої Г. Сльниковою [11] (табл. 3).

Таблиия 3

Кваліметрична (факторно-критеріальна) субмодель оцінювання компонентів результативності професійної діяльності науково-педагогічних працівників

\begin{tabular}{|c|c|c|c|c|}
\hline $\begin{array}{l}\text { № } \\
\text { 3/II }\end{array}$ & Фактори (Ф) & $\begin{array}{c}\text { Значимість } \\
\text { факторів (M) }\end{array}$ & $\begin{array}{c}\text { Компоненти результативності професійної } \\
\text { діяльності (критерії факторів) }\end{array}$ & $\begin{array}{l}\text { Значимість } \\
\text { критеріїв } \\
\text { (v) }\end{array}$ \\
\hline 1 & 2 & 3 & 4 & 5 \\
\hline & & & $\begin{array}{l}\text { 2. Нормативно-правовий (знання } \\
\text { нормативно-правової бази, уміння } \\
\text { раціонально використовувати закони в } \\
\text { освітній діяльності) }\end{array}$ & $v=0,09$ \\
\hline & & & $\begin{array}{l}\text { 3. Планово-прогностичний (уміння } \\
\text { планувати індивідуальну роботу студентів) }\end{array}$ & $v=0,08$ \\
\hline & & & $\begin{array}{l}\text { 4. Пізнавальний (формування } \\
\text { систематизованих, міждисциплінарних знань } \\
\text { студентів) }\end{array}$ & $v=0,08$ \\
\hline & & & $\begin{array}{l}\text { 5. Оцінно-аналітичний (оцінно- } \\
\text { рефлексивна діяльність, оволодіння } \\
\text { діагностичними методиками оцінювання }\end{array}$ & $v=0,11$ \\
\hline
\end{tabular}




\begin{tabular}{|c|c|c|c|c|}
\hline & & & $\begin{array}{l}\text { якісних показників творчого потенціалу } \\
\text { студентів) }\end{array}$ & \\
\hline & & & $\begin{array}{l}\text { 6. Технологічний (уміння моделювати, } \\
\text { проектувати, розробляти та застосовувати } \\
\text { нові технології, конструювати структуру } \\
\text { проблемних лекцій) }\end{array}$ & $v=0,08$ \\
\hline & & & $\begin{array}{l}\text { 7. Комунікативний (знання основ } \\
\text { комунікації, навички ефективної } \\
\text { комунікативної взаємодії) }\end{array}$ & $v=0,08$ \\
\hline & & & $\begin{array}{l}\text { 8. Концептуальний (володіння } \\
\text { інформаційними технологіями, уміння } \\
\text { розробляти плани, програми, проекти) }\end{array}$ & $v=0,11$ \\
\hline & & & $\begin{array}{l}\text { 9. Дослідницький (знання методології та } \\
\text { методики організації наукових досліджень) }\end{array}$ & $v=0,09$ \\
\hline & & & $\begin{array}{l}\text { 10. Мотиваційний (знання мотива- ційної } \\
\text { сфери студентів, уміння використовувати } \\
\text { систему мотивації для підвищення } \\
\text { результатів діяльності) }\end{array}$ & $v=0,08$ \\
\hline & & & $\begin{array}{l}\text { 11. Організаційний (організація } \\
\text { планування, основних видів робіт НПП, } \\
\text { видів НДРС, форм НДДС) }\end{array}$ & $v=0,11$ \\
\hline 2 & $\begin{array}{l}\text { Якості } \\
\text { особистості }\end{array}$ & $\mathrm{m} 2=0,24$ & $\begin{array}{l}\text { 12. Особистісний (індивідуальний стиль } \\
\text { діяльності, творчий потенціал, психолого- } \\
\text { фізіологічні властивості, якості, професійні } \\
\text { знання - теоретичні, методологічні) }\end{array}$ & $v=1,0$ \\
\hline 3 & Професійна & & $\begin{array}{l}\text { 13.Ключові компетенції (методологічні, } \\
\text { загальнометодичні, загальнотехнологічні } \\
\text { вміння та навички) }\end{array}$ & $v=0,34$ \\
\hline & $\begin{array}{l}\text { компетент- } \\
\text { ність }\end{array}$ & $\mathrm{m} 3=0,25$ & $\begin{array}{l}\text { 14. Загальноспеціальні компетенції } \\
\text { (інструментальні, комунікативні, системні) }\end{array}$ & $v=0,32$ \\
\hline & & & $\begin{array}{l}\text { 15. Спеціальні компетенції (методичні, } \\
\text { дослідницькі, технологічні) }\end{array}$ & $v=0,34$ \\
\hline 4 & Умови & & 16. Атестація & $\mathrm{v}=0,36$ \\
\hline & формування & & 17. Підвищення кваліфікації & $v=0,32$ \\
\hline & $\begin{array}{l}\text { професійної } \\
\text { компетентності }\end{array}$ & IIIT & 18. Наукові дослідження & $v=0,32$ \\
\hline
\end{tabular}

Фактор «готовність науково-педагогічних працівників до професійної діяльності» характеризується такими критеріями (компонентами): змістовий, нормативноправовий, особистісний, пізнавальний, оцінно-аналітичний, технологічний, комунікативний, концептуальний, дослідницький, мотиваційний, організаційний. Другий фактор - «якості особистості» характеризується особистісним критерієм (індивідуальний стиль діяльності, творчий потенціал, психолого-фізіологічні якості, професійні знання - теоретичні, методологічні). Третій фактор - «професійна компетентність» характеризується такими критеріями: ключові компетенції (методологічні, загальнометодичні, загальнотехнологічні вміння і навички, загальноспеціальні компетенції) (інструментальні, комунікативні, системні); спеціальні компетенції (методичні, дослідницькі, технологічні). Четвертий фактор - «умови формування професійної компетентності» характеризується критеріями, зокрема, атестація, підвищення кваліфікації, наукові дослідження. До кожного критерію (всього 18) розроблено по сім вимог відповідно [14, с. 180-184].

Головний критерій відбору i формування якісного складу НПП «результативність професійної діяльності». Факторів (критеріїв) відбору претендентів - 
всього чотири. Значимість цих факторів $(\mathrm{M})$ в цілому $(1,0)$ має відповідати високому або середньому рівню професійної спроможності (придатності) кандидата.

Попередньо ключові компетенції кандидатів експерти визначили на основі стандарту професійної діяльності відповідно до рівнів знань, умінь, навичок (методологічних, методичних, технологічних). Значимість критеріїв (v) компонентів рівня результативності професійної діяльності НПП у факторно-критеріальній субмоделі (всього 18) визначено групою експертів (їх було п'ять) на основі методу групового експертного оцінювання. Ці фактори та їх критерії ФКС інтегровано в спеціалізовану програму інформаційної системи, що дало змогу зіставити нормативні вимоги професії викладача 3 анкетними даними щодо психолого-фізіологічних характеристик претендентів і рівня професійного розвитку НПП і надати висновок про їх професійну придатність чи заміщення конкретної вакантної посади. Отже, на підставі отриманих даних 3 програми у діапазоні рівня від 0,66 до 1,0 можливо ухвалити позитивне рішення щодо кандидата.

Інтегровані компоненти результативності професійної діяльності в цілому відповідають критеріям оцінювання якостей викладачів, відповідно до яких можна характеризувати досягнення ними мети, їх конкретний внесок у результати діяльності колективу, динаміку просування в кар'єрі. Водночас оцінка інтегральних якостей і складників професіограми розглядається як критерій відбору - «готовність до професійної діяльності», що впливає на визначення рівня відповідності вимогам до претендентів.

На основі кваліметричної субмоделі визначено рівень сформованості конкретного компонента професійної діяльності науково-педагогічного працівника. Залучаючи експертів до кваліметрії, конкурсна комісія врахувала висновки IC про професійну спроможність, рівень професійного розвитку конкретного НПП, вказала на невикористаний творчий потенціал, шляхи вдосконалення педагогічної майстерності через спеціальну програму розвитку творчого потенціалу. Основою діагностичної програми професійного розвитку є кваліфікаційні вимоги до професійної діяльності НПП, зокрема, атестація, підвищення кваліфікації, конкурсний відбір НПП на заміщення вакантних посад, а також професійно-кваліфікаційна характеристика (відповідно до змісту професійної діяльності).

На етапі констатувального експерименту розроблено і використано анкету відповідно до критеріїв (результати навчально-виховної діяльності, методичний i науковий рівень викладання дисциплін, рівень навченості студентів), яка складалася 3 22 запитань. Кожне із запитань оцінене певним рангом від 0 до 3. Такі анкети були роздані у 2018 році 130 претендентам ДВНЗ «Переяслав-Хмельницький державний педагогічний університет імені Григорія Сковороди». Мета комп'ютерної діагностики передбачала визначення рівня професійної придатності претендента. Попередньо був установлений рівень професійної придатності претендентів: низький (до 30 балів); середній (від 30 до 40 балів); високий (більше 40 балів). На одну з чотирьох можливих відповідей претенденти проставляли знак «плюс». Претенденти, які набрали більше 40 балів на першому етапі відбору мали переваги на другому етапі конкурсного відбору.

Важливо було з'ясувати, як оцінюють експерти результати діяльності НПП щодо навчання майбутніх фахівців. Відтак визначено такі складники педагогічного професіоналізму: «якість знань студентів з навчальної дисципліни»; «залишкові знання 3 навчальної дисципліни»; «уміння користуватися отриманими знаннями»; «розуміння суті процесів і явищ у природі та суспільстві»; «рівень самостійності студентів, уміння самостійно здобувати знання»; «рівень обізнаності студентів з машинами, механізмами, технологіями, принципами їх роботи»; «ставлення до справи, соціальна активність, трудова діяльність, естетична та фізична культура». Оцінку складників педагогічного 
професіоналізму здійснили завідувачі кафедри, колеги по кафедрі, представники від органу студентського самоврядування, експерти, представники ректорату (здійснювалося також самооцінювання) за семибальною шкалою оцінок.

Достатньо високу факторну вагу має більшість означених складників. Найбільшу факторну вагу мають такі складники «розуміння суті процесів і явищ у природі і суспільстві», «ставлення до справи, соціальна активність, трудова діяльність, естетична та фізична культура» (табл. 4).

Таблиия 4

Ранжування факторної ваги складників педагогічного професіоналізму НПП

\begin{tabular}{|l|c|c|c|}
\hline \multicolumn{1}{|c|}{ Складник } & $\begin{array}{c}\text { Ранговий ряд за } \\
\text { оцінкою } \\
\text { експертів }\end{array}$ & $\begin{array}{c}\text { Факторна вага } \\
(a)\end{array}$ & $\begin{array}{c}\text { Ранговий ряд } \\
(a)\end{array}$ \\
\hline $\begin{array}{l}\text { 1. Якість знань студентів 3 навчальної } \\
\text { дисцпліни }\end{array}$ & 7 & 0,617 & $3 ; 4$ \\
\hline $\begin{array}{l}\text { 2. Залишкові знання з навчальної дисципліни } \\
\text { 3. Уміння користуватися отриманими } \\
\text { знаннями }\end{array}$ & 2 & 0,257 & $3 ; 4$ \\
\hline $\begin{array}{l}\text { 4. Розуміння суті процесів і явищ у природі та } \\
\text { суспільстві }\end{array}$ & 5 & 0,617 & $1 ; 2$ \\
\hline $\begin{array}{l}\text { 5. Рівень самостійності студентів, уміння } \\
\text { самостійно здобувати знання }\end{array}$ & 1 & 0,628 & 5 \\
\hline $\begin{array}{l}\text { б. Рівень обізнаності студентів } 3 \\
\text { машинами,механізмами,технологіями, } \\
\text { принципами іх роботи }\end{array}$ & 6 & 0,334 & 6 \\
\hline $\begin{array}{l}\text { 7. Ставлення до справи, соціальна активність, } \\
\text { трудова діяльність, естетична та фізична } \\
\text { культура }\end{array}$ & 4 & 0,628 & $1 ; 2$ \\
\hline
\end{tabular}

Нижче подано основний інтерфейс і приклад роботи програми.

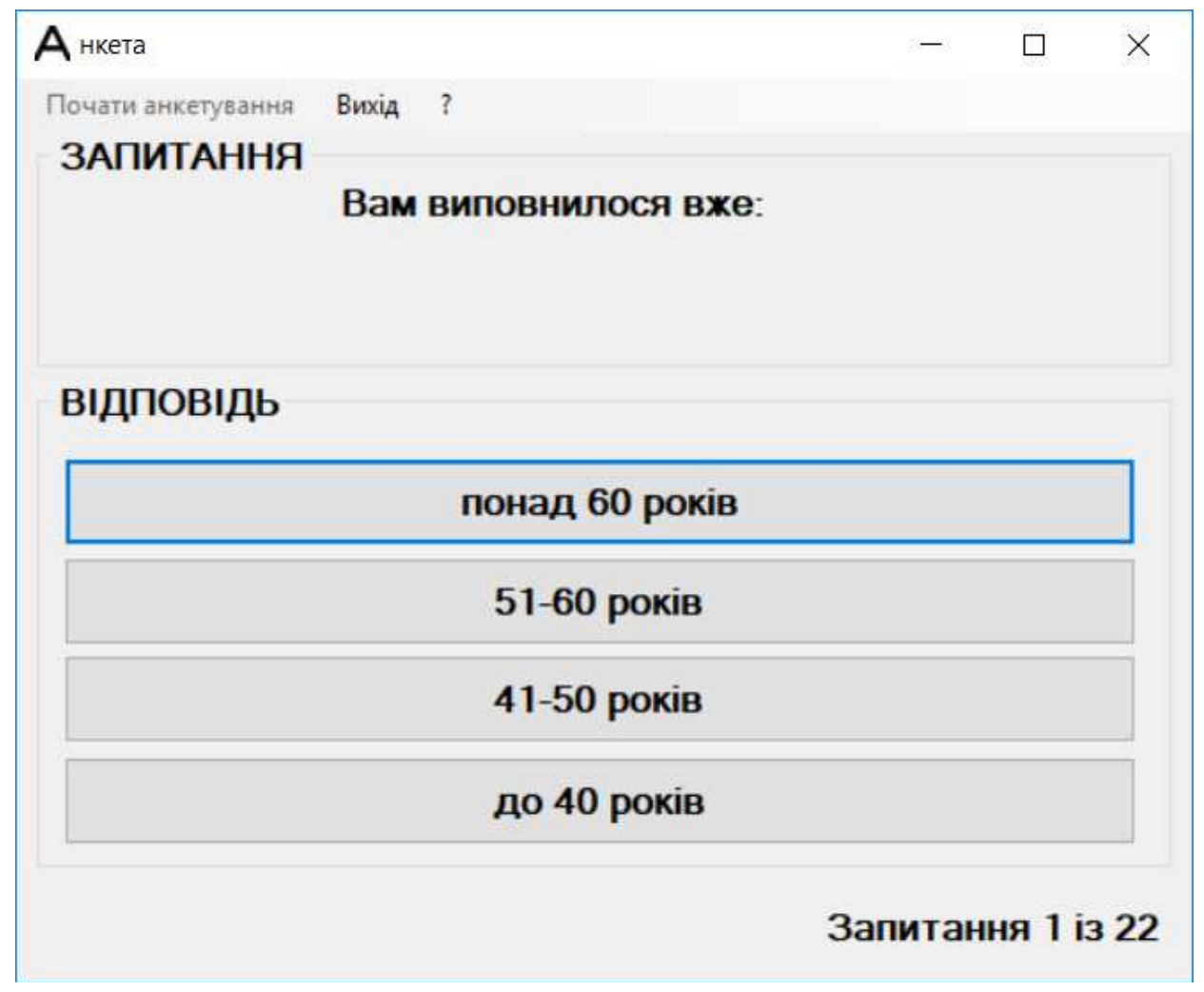


Ефективність функціонування програми виявляється в тому, що вона дає змогу визначити рівень професійної придатності претендентів, з'ясувати їх готовність до роботи в умовах вищої школи, визначити рівень сформованості якостей за результатами експертного оцінювання, а керівнику закладу вищої освіти прогнозувати успішну діяльність кандидатів у майбутньому. Оригінальною є також система PSI - KAPTA [15].

Використовуючи спосіб аналізу неметричних факторів (за допомогою шкал) можна вибудувати діагностичну карту - документ (у ньому проілюструвати вплив цих факторів на якісні показники професійної діяльності майбутнього викладача).

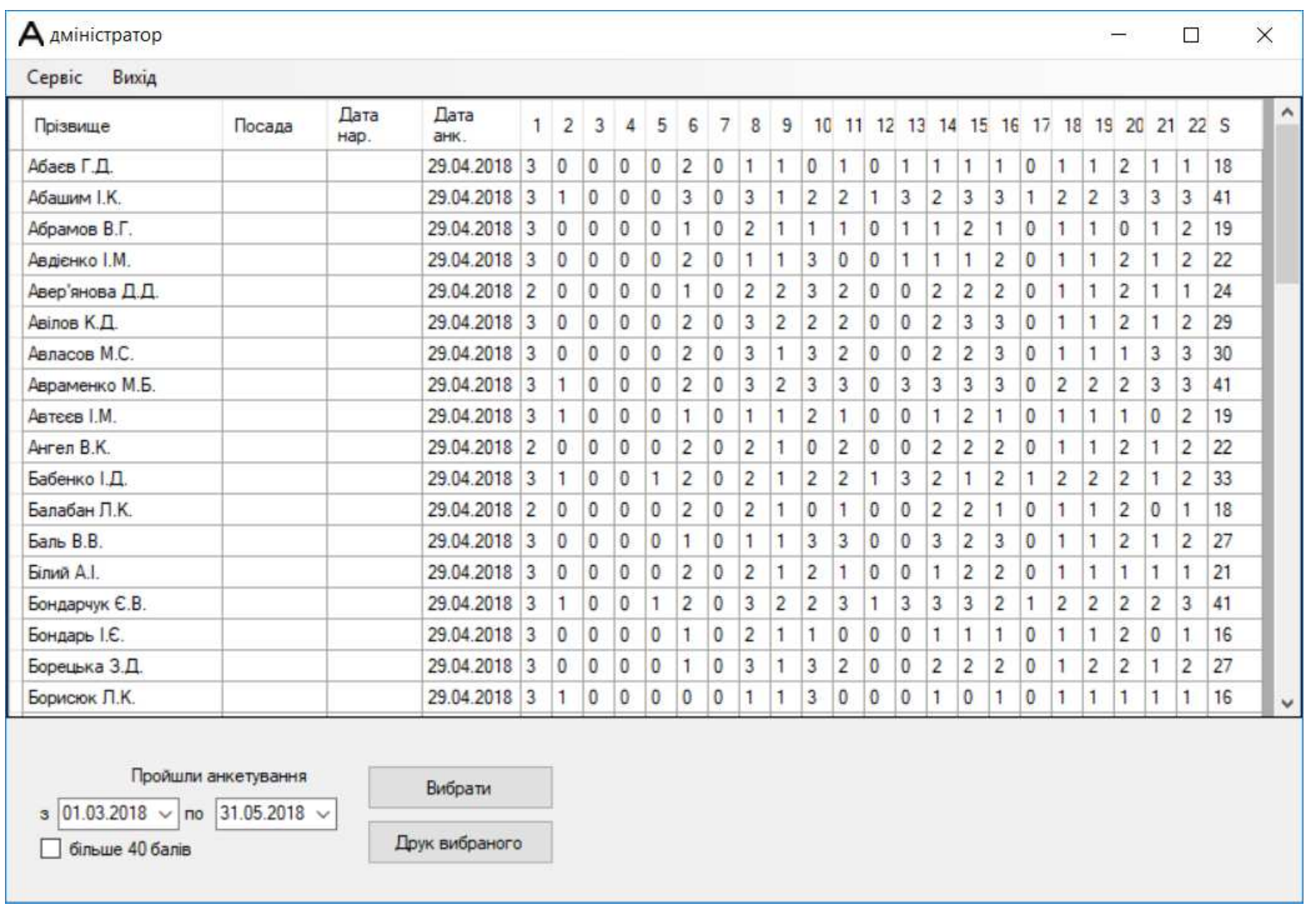

\section{4. ВИСНОВКИ І ПЕРСПЕКТИВИ ПОДАЛЬШИХ РОЗВІДОК}

Розроблено спеціальний програмний засіб для відбору кандидатів і формування якісного складу науково-педагогічних працівників, яка дає змогу відповідно до етапів організувати діагностичне оцінювання якостей, професійної придатності, моніторинг якісних показників рівня результативності професійної діяльності. Висновок експертів $\epsilon$ підставою для аналізу й коригування параметрів показників професійної діяльності в середньостроковій перспективі, програмування професійного розвитку НПП. Моніторингові процедури дали змогу зібрати дані про чинники, які вплинули на професійний розвиток науково-педагогічних працівників. Подальшими розвідками буде розроблення спеціальної каскадної програми розвитку науково-педагогічних працівників на основі програмно-цільового підходу до управління розвитком викладацького персоналу. 


\title{
СПИСОК ВИКОРИСТАНИХ ДЖЕРЕЛ
}

[1] "Положення про порядок проведення конкурсного відбору при заміщенні вакантних посад науково-педагогічних працівників та укладання з ними контрактів" [Електронний ресурс]. Режим доступу: http: // konkurs_vukladachi.pdf

[2] Закон України "Про вищу освіту", № 1556-VII, 2014 [Електронний ресурс]. Режим доступу: http: // search.ligazakon.ua

[3] "Рекомендації щодо проведення конкурсного відбору при заміщенні вакантних посад науковопедагогічних працівників та укладання 3 ними трудових договорів (контрактів)" [Електронний pecypc]. Режим доступу: http: // konkurs_vukladachi.pdf

[4] V. Y. Bykov, A. M. Gurgiy, G. O. Kozlakova, "The Development of Computer Education Ukraine Higher Technical School",Aplication and Impect Information Processing, vol. 2, pp. 678-681, 1994.

[5] H. V. Tereshchuk, I. M. Tsidylo. "Automated system of fuzzy identification of expert's competence for assessing the quality of pedagogical phenomena and processes",Information Technologies and Learning Tools, vol. 64, pp. 234-244, 2018.

[6] П. І. Бідюк, Проектування комп'ютерних інформаційних систем підтримки прийняття рішень, Київ, Київський політехнічний інститут, 2010.

[7] Е. Ю. Зайченко, "Многокритериальные задачи принятия решений в нечетких условиях", Системні дослідження та інформаційні технологї, №4, с. 79-87, 2016.

[8] Г. О. Козлакова, Теоретичні і методичні основи застосування інформаџійних технологій у вищій технологічній освіті, Інститут модернізації змісту освіти , Київ, 1997.

[9] О. В. Співаковський, "Особливості автоматизованих систем управління вищими навчальними закладами", Вісник Харківського національного університету, № 629, Вип. 3, с. 86-99, 2014.

[10] Х. С. Опаріна, "Сучасні методи відбору персоналу на підприємстві", Молодий вчений, № 5 (20), с. 38-44, 2015.

[11] Г. В. Сльникова, "Наукові основи адаптивного управління закладами та установами загальної середньої освіти", дис. доктора пед. наук, Університет менеджменту освіти, Київ, 2003.

[12] М. Короткова, "Построение системы поиска и подбора персонала", Менеджмент и менеджер, №2, c.54-58, 2005.

[13] Г. В. Назарова, "Технології відбору персоналу на базі сучасних програмних продуктів", Вісник Донбаської державної машинобудівної академії, №1, с. 162-165, 2012.

[14] В. О. Степашко, Освітній менеджмент: практичний аспект, Київ, Кафедра, 2017.

[15] "Інформація про систему PSI-KAPTA"[Електронний ресурс]. Режим доступу: http: // www.cogitocentre.com/page.php?al=14807

Матеріал надійшов до редакиії 06.06.2018p.

\section{ПРОГРАММНЫЕ СРЕДСТВА ОТБОРА И ФОРМИРОВАНИЯ ПРЕПОДАВАТЕЛЬСКОГО ПЕРСОНАЛА ЗАВЕДЕНИЯ ВЫСШЕГО ОБРАЗОВАНИЯ}

\author{
Степашко Владимир Алексеевич \\ доктор педагогических наук, профессор кафедры менеджмента, доцент \\ ГВУЗ «Переяслав-Хмельницкий государственный педагогический университет \\ имени Григория Сковороды», Переяслав-Хмельницкий, Украина \\ ORCID0000-0002-1367-6056 \\ quality16@i.ua
}

\begin{abstract}
Аннотация. В статье изложено проблему автоматизированного отбора кандидатов на вакантные должности и формирования качественного состава научно-педагогических работников с помощью специальной компьютерной программы. Актуальность проблемы состоит в необходимости отбора и формирования конкурентоспособного персонала, который обеспечит качественные образовательные услуги потребителям на основе новых информационных технологий. Разработаны аналитическая технология поддержки принятия решения в управлении процессом отбора и формирования преподавательского персонала, в частности, модель системы отбора и формирования качественного состава преподавательского персонала, компоненты профессиограммы преподавателя, факторнокритериальная субмодель для оценивания компонентов результативности
\end{abstract}


профессиональной деятельности научно-педагогических работников, специальная компьютерная программа для определения профессиональной пригодности претендентов. Определены уровни сформированности компонентов профессиональной деятельности научно-педагогических работников на основе факторно-критериальной субмодели, факторная масса и ранговый ряд компонентов педагогического профессионализма. Оценивание профессиональной способности и мониторинг качественных показателей профессиональной деятельности претендентов в процессе отбора, формирования и развития преподавательского персонала организовано на основе методов профессиографического анализа деятельности, факторно-критериального моделирования, компьютерного программирования, экспертного оценивания. Определены факторы, в частности, «готовность претендентов к профессиональной деятельности», «качества личности», «профессиональная компетентность», «условия формирования профессиональной компетентности» и в соответствии с ними компоненты результативности профессиональной деятельности. На основе разработанной квалиметрической факторно-критериальной субмодели определен уровень сформированности компонентов профессиональной деятельности научно-педагогических работников в соответствии с главным критерием «результативность профессиональной деятельности», факторную массу и ранговый ряд компонентов педагогического профессионализма. Высокий ранговый ряд имеют показатели «понимание студентами сущности процессов и явлений в природе и обществе», «отношение к делу, социальная активность, эстетическая и физическая культура».

Ключевые слова: заведение высшего образования; технология; профессиональный отбор; научно-педагогические работники; организационная модель; компьютерная программа; критерии оценивания качеств.

\title{
SOFTWARE FOR THE SELECTION AND FORMATION OF THE TEACHING STAFF OF HIGHER EDUCATION INSTITUTION
}

\author{
Volodymyr O. Stepashko \\ Doctor of Pedagogical Sciences, associate professor, \\ State Higher Educational Establishment «Pereiaslav-Khmelnytskyi Hrihorii Skovoroda \\ State Pedagogical University», Pereiaslav-Khmelnytskyi, Ukraine \\ ORCID 0000-0002-1367-6056 \\ quality16@i.ua
}

\begin{abstract}
The article outlines the challenge of automated selection of candidates for vacant positions and their right composition to secure the quality of teaching staff by means of the special computer programme. The urgency of the problem is the need to select and build a competitive team of professionals committed to providing high-quality educational services to consumers based on the latest information technologies. The analytical technology of decision-making support in the management of recruiting staff and creating academic structures has been developed. In particular, the model of selection and composition of quality teaching staff and components of their job descriptions, factor-criterial submodel for the evaluation of the performance components of the teaching staff professional activity, the special computer software to determine applicants' occupational suitability. Assessment of professional competence and monitoring of the qualitative indicators of the applicants' professional activity in selection, formation and professional development of teaching staff as well as in creating academic structures have been carried out on the basis of professional activity analysis methods, factorcriterial modeling, computer programming, and expert evaluation. Such factors as "applicants' readiness for professional activity", "personality qualities", "professional competence", "conditions of professional competence development" have been singled out, and it has resulted in creating components of professional efficiency. On the basis of developed qualimetric factorcriterial submodel, the level of formation of teaching staff professional activity components has been determined in accordance with the main criterion of "professional efficiency", as well as the factor weight and the rank number of pedagogical professionalism components. The high ranked series have indicators of "students' understanding of the essence of processes and phenomena in nature and society", "commitment, social activity, aesthetic and physical culture".
\end{abstract}


Keywords: higher educational establishment; technology; professional selection; research and teaching staff; organizational model; computer programme; criteria for evaluating the qualities.

\section{REFERENCES (TRANSLATED AND TRANSLITERATED)}

[1] "Regulation on the procedure for competitive selection when replacing vacant posts of academic staff and concluding contracts with them" [Online]. Available: http: // konkurs_vukladachi.pdf (in Ukrainian).

[2] Law of Ukraine on higher education, № 1556-VII, 2014 [Online]. Available:http: // search.ligazakon.ua(in Ukrainian).

[3] "Recommendations on conducting competitive selection when replacing vacant posts of academic staff and concluding labor agreements (contracts) with them" [Online]. Available: http: // konkurs_vukladachi.pdf (in Ukrainian).

[4] V. Y. Bykov, A. M. Gurgiy, G. O. Kozlakova, "The Development of Computer Education Ukraine Higher Technical School", Aplication and Impect Information Processing, vol. 2, pp. 678-681, 1994 (in German).

[5] H. V. Tereshchuk, I. M. Tsidylo. "Automated system of fuzzy identification of expert's competence for assessing the quality of pedagogical phenomena and processes", Information Technologies and Learning Tools, vol. 64, pp. 234-244, 2018 (in Ukrainian).

[6] P. I. Bidiuk, L. O.Korshevniuk, Design of computer information systems for decision-making support, Kyiv, Kyiv Politechnic Institute, 2010 (in Ukrainian).

[7] E. Yu. Zaichenko, Yu. P.Zaichenko, "Multi-criteria decision-making tasks in ambiguous terms",System research and information technology, №.4, pp. 79-87, 2016 (in Ukrainian).

[8] G. O. Kozlakova, "Theoretical and methodological bases of information technologies in higher technological education", monograf, Institute of education content modernization, Kyiv, 1997 (in Ukrainian).

[9] A. V. Spivakovskii, "Features of automated control systems by higher educational institutions", Visnyk of Kharkiv National University, vol. 3, pp. 86-99, 2004 (in Ukrainian).

[10] H. S. Oparin, "Modern Methods of Personnel Selection at an Enterprise", Molodiy vcheniy, № 5 (20), c. 38-44, 2015. (in Ukrainian).

[11] G. V. Yelnykova, "Scientific fundamentals of adaptive management of institutions and institutions of general secondary education", pp. 314-315,2003 (in Ukrainian).

[12] M. Korotkova, "Development of the system of search and selection of personnel",Management and Manager, № 2,pp. 54-58, 2005 (in Russian).

[13] G. V. Nazarova, "Technologies os personnel selection on the basis of modern software products", Visnyk of Donbas State Engineering Academy, №1 (26), pp. 162-165, 2012 (in Ukrainian).

[14] V. O. Stepashko, Educational Management: Practical Aspect, Kyiv, Kafedra, 2017 (in Ukrainian).

[15] "PSI-CARD system information"[Online].Available: http://www.cogito-centre.com/page.php?al=14807 (in Ukrainian).

\section{(c) $\mathrm{EY}-\mathrm{NC}-\mathrm{SA}$}

This work is licensed under Creative Commons Attribution-NonCommercial-ShareAlike 4.0 International License. 